\title{
HOSPITAL'S CRIMINAL LIABILITY FOR PATIENT'S DAMAGES DUE TO HEALTH SERVICE ERRORS DURING THE COVID-19 PANDEMIC
}

\author{
Diana Yusyanti \\ Researcher of Badan Penelitian dan Pengembangan Hukum dan Hak Asasi Manusia, \\ Kementerian Hukum dan Hak Asasi Manusia Republik Indonesia, Jakarta. \\ Corresponding author. Email: deon.zus@gmail.com \\ Paper received on: 18-10-2021, Revised on: 11-11-2021, Approved to be published on: 23-11-2021 \\ DOI: http://dx.doi.org/10.30641/dejure.2021.V21.489-506
}

\begin{abstract}
During the Covid-19 pandemic, many mass media reported various cases of health service errors at hospitals that resulted in material losses, there were even cases of patients dying. The criminal aspect is explicitly stated in the provisions of Article 190 of Law No. 36 Year 2009 and Article 62 and Article 63 of Law No. 44 Year 2009 and Article 46 of Law Number 44 Year 2009 concerning Hospitals where it is stated that hospitals are legally responsible for all losses due to negligence or health service errors. This research used descriptive normative research through a statutory approach, carried out by reviewing all laws related to legal issues that are being handled. In addition, criminal sanctions in Law Number 36 Year 2009 are formulated cumulatively, such as in the case of criminal acts as referred to in Article 190 paragraph (1), Article 191, Article 192, Article 196, Article 197, Article 198, Article 199, and Article 200, accumulated so that the general provisions in Article 30 of the Criminal Code are ineffective, that the maximum sanction if not paid the perpetrators are only subject to a substitute imprisonment of 6 months or 8 months.
\end{abstract}

Keywords: criminal liability; covid-19 referral hospitals; patients

\section{INTRODUCTION}

The Covid-19 virus pandemic has been going on since 2020 and until now there is no sign that it will end. The Indonesian government continues to try to suppress the increase in the number of people infected with Covid-19 in various ways. Starting from the large-scale social restrictions (PSBB) which took effect in April 2020, then in January 2021 the first community activity restrictions (PPKM) was carried out. In early July 2021, the government again imposed an emergency PPKM due to the increasing number of cases of people infected with Covid-19, even adding treatment facilities, and education on health protocols for the community. Another effort is the acceleration of Covid-19 vaccination in various regions. The Regulation of the Minister of Health Number 9 Year 2020 concerning Guidelines for Large-Scale Social Restrictions in the Context of Accelerating the Handling of Corona Virus Disease 2019 (COVID-19). The guidelines for the prevention and control of COVID-19 were prepared based on WHO recommendations adapted to the development of the COVID-19 pandemic, and the provisions of the applicable laws and regulations.
The government at that time had planned to create a scenario called the new normal, this option was based on the view of the WHO which revealed that it would take a long time to find an anti-virus. In line with WHO, President Joko Widodo also said that humans must coexist with this virus. New normal provides a number of flexibility to the public with health protocols. The new normal that we know today is actually not new. It is recorded in world history that the pandemic that occurs is a 100 -year cycle, perhaps so that the universe finds its balance again. ${ }^{1}$ The legal basis for the Prevention and Control of Covid-19 is Presidential Decree Number 11 Year 2020 concerning the Determination of the Corona Virus Disease 2019 (COVID-19) Public Health Emergency. Presidential Decree Number 12 Year 2020 concerning the Determination of NonNatural Disaster of the Spread of Corona Virus Disease 2019 (COVID-19) as National Disaster.

The spread of the Covid-19 has had an impact on various sectors. Starting from the economy,

\footnotetext{
Suparto Wijoyo, "Webinar Nasional," in Tantangan New Normal dan dampaknya terhadap Rekonstruksi Hukum Lingkungan (Surabaya: PPI UINSA 28 Agustus, 2020).
} 
tourism, transportation, politics to public services. From the economic side, the scarcity of various kinds of needs began to be felt, even in some places. Another sector affected is public services. In the midst of the outbreak of the Corona Virus in our country, public services must continue to run, but not as much as under normal circumstances. Various policies were taken to keep the services running. Currently, the public services that are most in the spotlight are hospitals, especially hospitals that are referrals for patients infected with Covid-19. Hospitals had prepared a number of services to anticipate the surge in the number of Covid-19 patients in the country. In the midst of the Covid-19 pandemic like this, there are still health services that are not in accordance with applicable health procedures, for example the case in a hospital in Jombang where a mother who gave birth was not treated immediately so that the baby's life was not saved, as well as the case of wrong gender identification of a newborn that happened in Nganjuk. Legally, this has violated the applicable laws and regulations, especially those related to health. This is in accordance with what is stated in Article 28H (1) of the 1945 Constitution which states that: "Everyone has the right to live in physical and spiritual prosperity, to have a place to live, and to have a good and healthy living environment and have the right to obtain health services". It is a statement of the state constitution of the Republic of Indonesia towards citizens to have a healthy life and the right to obtain health services.

Examples of cases in the midst of the Covid-19 pandemic like this showed there are still health services that are not in accordance with applicable health procedures, such as the case in a hospital in Jombang where a mother who gave birth was not immediately treated so that the baby's life was not saved, and the case of wrong gender identification of a newborn in Nganjuk. Legally, this has violated the applicable laws and regulations, especially those related to health. ${ }^{2}$ In addition, Article 32 of Law No. 44 Year 2009 concerning Hospitals regulates the rights received

\footnotetext{
Eko Budiono, "Ganti Rugiatas Kelalaiandan Kesalahan dalam Pelayanan Kesehatan”," https://ekobudiono. lawyer/, last modified 2020, https://ekobudiono. lawyer/2020/o9/26/ganti-rugi-atas-kelalaian-dankesalahan-dalam-pelayanan-kesehatan/. Di akses tanggal 26 September 2021
}

by patients in hospitals, including: patients have the right to receive services that are humane, fair, honest, and without discrimination; obtain quality health services in accordance with professional standards and standard operating procedures. In addition, Article 43 regulates patient safety standards, which are carried out through incident reporting, analyzing, and determining solutions in order to reduce the number of unexpected events. In addition to the two cases, there were also shocking cases which were detrimental to the state and society, such as the case of health mafia, among others: ${ }^{3}$ Chairman of the IPW Presidium, Neta S Pane, said that as a result of the health mafia's action, three things which were detrimental to the state and society occurred. First, the validity of the number of Covid-19 victims in Indonesia, especially those who died, is inaccurate. Second, the state is at a loss because the state budget for Covid-19 victims is robbed by the health mafia. Third, the families of the victims who were infected with Covid-19 by the health mafia have been ostracized by the surrounding community who are afraid that the virus will spread to them. According to the information obtained by IPW, the cost of treating patients infected with the corona virus can reach IDR 290 million. The Decree of the Minister of Finance Number S-275/MK 02/2020 dated April 6, 2020 contains the rules and the amount of the cost of treating Covid-19 patients. If a patient is treated for 14 days, the assumption is that the government will bear the cost of IDR 105 million as the lowest cost. As for patients with complications, the government must at least bear the cost of IDR 231 million per person. For this reason, the Criminal Investigation Division (Bareskrim) needs to investigate and audit all Covid-19 referral hospitals to find out how many victims actually died from Covid-19 and how many victims were deemed to be infected by Covid. On April 27, 2020, for example, said Neta, the North Sumatera Task Force for the Acceleration of Handling Covid 19 announced that of the 61 patients buried under the Covid 19 procedure, 43 of them were found to be negative for Covid-19. Then on July 14, 2020,

3 Ichwan Fajar, IPW: Negara dan Warga Dirugikan Mafia Kesehatan saat Pandemi, 5 Oktober 2020. https:// www.tagar.id/ipw-negara-dan-warga-dirugikanmafia-kesehatan-saat-pandemi. Di akses 2 Oktober 2021 
six graves at the Teluk Kabung Public Cemetery, Padang, West Sumatra which were buried with the Covid-19 procedure were dug at the request of the family because their test results were negative for Covid. On June 8, 2020, Ade Margani’s family sued the Balaraja Hospital, Banten, because the person concerned was buried with the Covid-19 procedure even though the test result was negative. These various cases of Covid-19 are clearly very disturbing to the community.

Indonesian Medical Discipline and in Paragraph (3) it is explained that even though a complaint has been made, it does not eliminate the right of everyone to report an alleged criminal act to the competent authorities and/or to file a lawsuit for civil damages to the court. Law No. 44 Year 2009 concerning Hospitals in Article 46 states "Hospitals are legally responsible for all losses caused by negligence committed by health workers in hospitals". Therefore, a hospital shall be responsible for negligence of health workers who carry out work that is the responsibility of the hospital.

Patients in an emergency situation are patients who are in a sudden situation that require treatment or aid quickly, precisely, and carefully so that the patients can avoid death or disability. Patients in an emergency situation need primary aid in a hospital. One form of medical service that is required to exist is the Emergency Department (ED) where currently many Covid-19 patients whose treatment is too late are brought to the ED. Emergency conditions for patient care in hospitals have the criteria as stated in Article 3 of the Regulation of the Minister of Health Number 47/2018 which regulates emergency criteria including: life threatening, endangering self and other people/environment;

1. the presence of disturbances in the airway, breathing, and circulation;

2. there is a loss of consciousness;

3. the presence of hemodynamic disorders; and/ or

4. requiring immediate action.

Seeing the above, specifically for patients in emergency conditions, who require preventive measures, which must be carried out quickly by health workers in hospitals, so that there is no disability or death in patients, which usually occurs in the Emergency Department or ED. As stated in article 32 of Law number 36 Year 2009 concerning Health, in this emergency condition, hospitals are prohibited from refusing patients or asking for advances. ${ }^{4}$

Likewise, some Covid-19 patients who enter the ED are provided with facilities to restore health, such as providing health facilities as needed in various hospitals. However, the number of deaths from Covid-19 has continued to soar in recent weeks. Minister of Health Budi Gunadi Sadikin said that $20 \%$ of corona patients who entered hospitals' Emergency Department (ED) died. This number increased from $1 \%$ to $2 \%$ who died when brought to the ED. ${ }^{5}$

Several cases were found as collected by the WowKeren Team in August 2021, including: various stories were present in the midst of efforts to control the COVID-19 pandemic, including patients who claim to have to pay a large amount of medical expenses after being confirmed positive for COVID-19.

Albajili, through his written statement, Wednesday (18/8). "The one who complains about the financing of treatment and the purchase of medicines at the hospital." Like one of the informants who in June 2021 had to put his mother in a referral hospital due to COVID-19. The informant was finally asked to pay IDR 600 million. A different story was told by a family in Denpasar, Bali, who was asked by a hospital to buy Gammaraas medicine worth IDR 220 million in July 2021. LBH Jakarta also admitted to receiving complaints from patients who were asked to pay up to IDR 225 million by hospitals. "On the grounds that the government-funded treatment period is only 14 days." The coalition strongly condemns this practice because it violates the Decree of the Minister of Health Number 01.07/ MENKES/104/2020 which stipulates that claims for treating COVID-19 patients shall be charged to the Ministry of Health through the Directorate General of Health Services.

\footnotetext{
4 Undang-Undang Republik Indonesia, Lihat Pasal 32 Undang-undang nomor 36 tahun 2009 tentang kesehatan ayat (1) dan (2) (Republik Indonesia, 2009).

5 Rizky Alika, "Terlambat Masuk Rumah Sakit, 20\% Pasien Covid-19 Meninggal di IGD," Dhttps://katadata. co.id/, last modified 2021, https://katadata.co.id/ ameidyonasution/berita/6107a351b76e3/terlambatmasuk-rumah-sakit-20-pasien-Covid-19-meninggaldi-igd.Diakses 1 September 2021
} 
Article 32 of Law No. 44 Year 2009 concerning Hospitals regulates the rights received by patients in hospitals, including: patients have the right to receive services that are humane, fair, honest, and without discrimination; obtain quality health services in accordance with professional standards and standard operating procedures. In addition, Article 43 regulates patient safety standards, which are carried out through incident reporting, analyzing, and determining solutions in order to reduce the number of unexpected events. With the patient safety standards regulated in Law No. 44 Year 2009 concerning Hospitals, events that cause death due to negligence of medical personnel should be able to be avoided, considering that patient safety standards are clear and must be implemented. Law No. 36 Year 2009 concerning Health in Articles 4 to 8 regulates the rights of everyone to health. In Article 5 Paragraph (2) it is emphasized that everyone has the right to obtain safe, quality, and affordable health services. Everyone who feels damaged by negligence or error in the health services he receives has the right to claim compensation. This is regulated in Article 58 Paragraph (1) of Law No. 36 Year 2009 concerning Health which reads, "Everyone has the right to claim compensation to a person, health workers, and/or health providers who cause losses due to errors or negligence in the health services they receive.” In Law No. 29 Year 2004 concerning Medical Practice in Article 66 it is stated that any person whose interests are harmed by the actions of a doctor in carrying out medical practice can make a written complaint to the Chairman of the Indonesian Medical Discipline Honorary Council and in Paragraph (3) it is explained that even though a complaint has been made, it does not eliminate the rights of everyone to report suspected criminal acts to the competent authorities and/or claim civil damages to the court. Seeing this, the question arises: How is the responsibility of the hospital head in the event of a health service error that harms patients during the Covid-19 pandemic period?

\section{RESEARCHMETHOD}

The research method used in this paper is normative legal research method, namely research conducted by reviewing applicable laws and regulations or applied to a particular legal problem. Data collection was carried out through literature study (secondary data). Sources of Data/ Legal Materials. Secondary data is data obtained from library research and documents, which are the results of research and processing by others, which are already available in the form of books or documents and usually provided in libraries, or privately owned. Secondary data were obtained from primary materials, secondary legal materials, and tertiary legal materials, laws and regulations related to the problems of patient health services in hospitals during the Covid-19 pandemic.

As for secondary materials, namely materials that are closely related to primary legal materials and can help analyze and understand primary legal materials, they were obtained from books, research journals and tertiary legal materials, namely materials that provide information about primary legal materials and secondary legal materials. The data were inventoried, classified and compiled comprehensively. This was done through manual or electronic searches.

\section{DISCUSSION AND ANALYSIS}

\section{A. Health Services and Hospital Rights and Responsibilities}

Ahospital isaunique and complex workplace, not only providing health services for the community, but also a place for medical education and research. The wider the health services and functions of a hospital, the more complex the equipment and facilities. The complexity that includes all of these causes the hospital to have a very large potential danger, not only for patients and medical personnel, this risk also endangers hospital visitors. ${ }^{6}$

A hospital is a health service institution that provides complete individual health services including inpatient, outpatient, and emergency services. Hospitals are run based on Pancasila and are based on human values, ethics and professionalism, benefits, justice, equal rights and anti-discrimination, equity, patient protection and safety, and have social functions. ${ }^{7}$

Hospital according to the regulation of

\footnotetext{
6 Darmadi, Infeksi Nosokomial Problematika Dan Pengendaliannya, Salemba Medika (Jakarta: Salemba Medika, 2008).hlm 1

7 Undang-Undang Republik Indonesia, UndangUndang Nomor 44 Tahun 2009 tentang Rumah Sakit (Republik Indonesia, 2009).
} 
the Minister of Health Number 47 Year 2018 concerning emergency services is a health service institution that provides complete individual health services including inpatient, outpatient, and emergency services.

Article 1 number 1 of Law Number 44 Year 2009 concerning Hospitals states that: "A hospital is a complete individual health service institution that provides inpatient, outpatient, and emergency services.”

According to Article 1 number 2 of Law Number 36 Year 2014 concerning Health Workers, it is stated that: "Health facilities are places which are used to provide medicalmeasures.” Meanwhile, Article 1 number 1 of the Regulation of the Minister of Health of the Republic of Indonesia Number 1045 Year 2006 concerning Guidelines for Hospital Organization in the Environment of the Department of Health states that a hospital is an individual health service facility that provides inpatient and outpatient services and provides short-term and long-term health services consisting of observation, diagnostic, therapeutic, and rehabilitative treatment for people suffering from illness, injury and childbirth.

In the Decree of the Minister of Health of the Republic of Indonesia No. 129 Year 2008 concerning Minimum Service Standards for Hospitals, it is stated that every hospital is required to have a minimum service standard. Minimum service standards are provisions regarding the type and quality of basic services which are mandatory regional affairs that every citizen has the right to obtain at a minimum. In addition, it is also a technical specification regarding the minimum service standards provided by the Public Service Agency. This minimum service standard can be used as a reference for hospital managers and related elements in planning, financing and implementing each type of service.

\section{Hospital Principles and Goals}

In Article 2 of Law Number 44 Year 2009 concerning Hospitals, it is stated that: Hospitals are run based on Pancasila and are based on human values, ethics and professionalism, benefits, justice, equal rights and anti-discrimination, equity, patient protection and safety, and have social function.

The purpose of operating a hospital cannot be separated from the provision that the community has the right to health as formulated in various provisions of the law, one of which is Law 43 Number 36 Year 2009 concerning Health. Meanwhile, the government has the responsibility to realize the highest degree of health, including by providing health facilities as needed, and one of the health service facilities is a hospital. ${ }^{8}$

\section{Hospital Rights and Obligations}

In Articles 29 and 3 of Law No. 44 Year 2009 concerning Hospitals

\section{a. Hospital Obligations}

1) to provide correct information about hospital services to the community

2) to provide safe, quality, antidiscriminatory, and effective health services by prioritizing the interests of patients in accordance with hospital service standards

3) to provide emergency services to patients in accordance with their service capabilities

4) to play an active role in providing health services in disasters, in accordance with their service capabilities

5) to provide facilities and services for the underprivileged or poor people

6) to carry out social functions, among others, by providing service facilities for underprivileged/poor patients, emergency services without a down payment, free ambulances, services for victims of disasters and extraordinary events, or social services for humanitarian missions

7) to create, implement, and maintain quality standards of health services in hospitals as a reference in serving patients;

8) to maintain medical records; i. providing proper public facilities and infrastructure, including worship facilities, parking area, waiting rooms, facilities for disabled people, breastfeeding women, children, the elderly

9) to implement a referral system

\footnotetext{
8 Endang Wahyati Yustina, Mengenal Hukum Rumah
} Sakit (Bandung: Keni Media, 2012). 
10) to reject patients'wishes that are contrary to professional and ethical standards as well as laws and regulations

11) to provide correct, clear and honest information regarding the rights and obligations of patients

12) to respect and to protect patient rights

13) to implement hospital ethics

14) to have an accident prevention and disaster management system;

15) to implement government programs in the health sector both regionally and nationally

16) to make a list of medical personnel who practice medicine or dentistry and other health workers

17) to compile and to implement hospital internal regulations

18) to protect and to provide legal aid for all hospital staff in carrying out their duties

19) to treat the entire hospital environment as a smoke-free area.

Violations of obligations are subject to administrative sanctions in the form of:

1) Reprimand

2) written warning

3) fines and revocation of hospital permits.

Further provisions regarding hospital obligations are regulated by a Ministerial Regulation.

\section{b. Hospitals have rights to:}

1) determine the number, type, and qualification of human resources according to the hospital classification

2) receive service fees and determine remuneration, incentives, and awards in accordance with the provisions of laws and regulations

3) cooperate with other parties in order to develop services

4) receive assistance from other parties in accordance with the provisions of laws and regulations

5) sue a party that caused loss

6) get legal protection in carrying out health services
7) promote the health services in the hospital in accordance with the provisions of laws and regulations

8) get tax incentives for public hospitals and hospitals that are designated as teaching hospitals.

9) Further provisions regarding the promotion of health services are regulated by a Ministerial Regulation

10) Further provisions regarding tax incentives are regulated by a Government Regulation.

\section{c. Patients and Health Services and their Rights and Obligations}

\section{The Definition of Patient}

According to the Great Dictionary of the Indonesian language, a patient is a sick person who is treated by a doctor or person with illness. ${ }^{9}$ The definition of a patient in Article 1 point 10 of Law Number 29 Year 2004 concerning Medical Practice is anyone who consults about his health problems to obtain the necessary health services, either directly or indirectly, with a doctor or dentist. Patient or sick person is a person who receives medical treatment, the word pasien (patient) from Indonesian language is analogous to the word patient from English, patient is derived from Latin, namely patiens which has the same meaning as the verb pati which means "to suffer", sick person (who is treated by a doctor), sufferer (sick). ${ }^{10}$ Meanwhile, according to the Regulation of the Minister of Health of the Republic of Indonesia Number 269/Menkes/Per/III/2008, a patient is anyone who consults about health problems to obtain the necessary health services, either directly or indirectly, with a doctor or dentist. According to Wila Chandrawila Supriadi, a patient is a sick person who needs the help of a doctor to cure his illness, and a patient is defined as a sick person who is ignorant of his illness. ${ }^{11}$

According to the Regulation of the Minister of Health of the Republic of Indonesia

\footnotetext{
9 Kamus Besar Bahasa Indonesia, "Pengertian Pasien" (Jakarta: https://kbbi.web.id, 2021), https://kbbi.web. id/pasien.Diakses 6-10-2001

1o A.Z. Nasution, Hukum Perlindungan Konsumen Suatu Penganta. (Jakarta: Diadit Media, 2001), 3.

"Titik Triwulan Tutik dan Shita Febriana, Perlindungan Hukum Bagi Pasien (Jakarta: Prestasi Pusataka, 2010). Hlm 14
} 
(PERMENKES RI) Number 69 Year 2014 concerning Hospital Obligations and Patient Obligations, Article 1 Number 2 states that "Patient is any person who consults about health problems to obtain the necessary health services, either directly or indirectly, in a hospital.”

\section{Health Services}

The General Provisions in the Health Law do not clearly state Health Services, but this is reflected in Article 1 of the General Provisions paragraph (4) that health efforts are any activity and/or series of activities carried out for the purpose of public health. Although it is not clearly explained about health services, we can understand it through the definitions put forward by scholars as follows:

Health Services, Health services consist of a) individual health services b) public health services.

These health services include activities with promotive, preventive, curative and rehabilitative approaches. Individual health services are aimed at curing disease and restoring the health of individuals and families. Public health services are aimed at maintaining and improving health and preventing disease in a group and society. The implementation of health services as referred to must prioritize the safety of the patient's life over other interests. Article 54 (1) of the Health Law states that the implementation of health services shall be carried out in a responsible, safe, quality, as well as equitable and non-discriminatory manner.

(2) The government and regional governments shall be responsible for the implementation of health services as referred to in paragraph (1).

(3) Supervision of the implementation of health services as referred to in paragraph (1) shall be carried out by the Government, regional governments, and the community. Article 55

(1) The government is obliged to determine the quality standard of health services. (2) The quality standard of health services as referred to in paragraph (1) shall be regulated by a Government Regulation.

\section{Health Service Facilities}

Health service facilities, according to Law Number 36 Year 2009 concerning Health, the types of services consist of:
a. individual health services; and
b. public health services.

\section{Health service facilities include}

1) first-level health services

2) second-level health services

3) third-level health services.

The health service facilities as referred to shall be carried out by the Government, regional governments, and the private sector. The provisions of the requirements for health service facilities as referred to above shall be stipulated by the Government in accordance with the applicable provisions. The provisions for licensing health service facilities as referred to shall be stipulated by the Government and regional governments, among others:

a) to provide broad access to research and development needs in the health sector

b) to send a report on the results of research and development to the regional government or the Minister. In an emergency, health service facilities, both from government and private sector, are required to provide health services to save patient lives and prevent disability first.

In an emergency, health services facilities, both from government and private sector, are prohibited from refusing patients and/or asking for a down payment.

The health law states that every head of the administration of public health service facilities must have the required public health management competency. The competence of public health management as referred to is further regulated by a Ministerial Regulation.

Each head of the administration of individual health service facilities must have the required individual health management competency. Providers of health service facilities are prohibited from employing health workers who do not have the qualifications and permits to do professional work. The provisions referred to shall be implemented in accordance with the provisions of laws and regulations.

According to Law Number 36 Year 2009 concerning Health, it is stated that regional governments can determine the number and types of health service facilities and grant operating permits in their area. The determination of the number and type of health service facilities as referred to shall be carried out by the regional government by taking into account: 

a) the area
b) health needs
c) the number and distribution of the population
d) disease pattern
e) its use
f) social function
g) ability to utilize technology.

The provisions regarding the number and types of health service facilities and the granting of operating permits as referred to shall also apply to foreign health service facilities. Provisions regarding the number and types of health service facilities as referred to shall not apply to the types of special hospitals for quarantine, research, and asylum. Further provisions regarding the operation of health service facilities as referred to shall be regulated by a Government Regulation.

\section{Patient's Rights and Obligations}

The patient's right is actually a basic right that comes from the basic rights of individuals in the health sector (the right of self-determination), although it is actually the same fundamental, but the right to health services is often considered more basic. In the doctor-patient relationship, the patient is relatively in a weak position. The inability of patients to defend their interests in health service situations causes the need to raise concerns about patient rights in dealing with health professionals. ${ }^{12}$

According to Soerjono Soekanto, the patient's rights are derived from the right to himself, therefore patients are independent legal subjects who are considered to be able to make decisions for their own interests where previously the relationship between doctors and patients was more paternalistic, patients generally could only accept everything that was said by doctors without being able to ask anything. ${ }^{13}$

Patients' obligations according to article 31 of Law No. 44 Year 2009 are as follows: ${ }^{14}$

1. Every patient has an obligation to the hospital for the services he receives

12 Danny Wiradharma, Penuntun Kuliah Hukum Kedokteran (Jakarta: CV Sagung Seto, 2010).

13 Soerjono Soekanto, Segi-Segi Hukum Hak Dan Kewajiban Pasien dalam Krangka Hukum Kesehatan (Jakarta: CV Mandar Maju, 1990). Hlm 27

14 Indonesia, Undang-Undang Nomor 44 Tahun 2009 tentang Rumah Sakit.
2. Further provisions regarding patient's obligations are regulated by a Ministerial Regulation.

The Regulation of the Minister of Health Number 69 Year 2014 is as follows: ${ }^{15}$

1. to comply with the applicable regulations in hospitals;

2. to use hospital facilities responsibly;

3. to respect the rights of other patients, visitors and the rights of Health Workers and other officers who work in hospitals;

4. to provide honest, complete and accurate information according to their abilities and knowledge about their health problems;

5. to provide information about their financial capabilities and health security that they have

6. to comply with the therapy plan recommended by the health worker in the hospital and approved by the patient concerned after receiving an explanation in accordance with the provisions of laws and regulations;

7. to accept all the consequences of his personal decision to refuse the therapy plan recommended by the Health Worker and/or not to comply with the instructions given by the Health Worker in the context of curing his illness or health problem; and

8. to provide compensation for services received

According to Law No. 29 Year 2004: Law on Medical Practice, patients in receiving services have the following obligations: ${ }^{16}$

1. to provide complete and honest information about their health problems.

2. to comply with the advice and instructions from a doctor or dentist.

3. to comply with the applicable provisions of health service facilities.

4. to provide compensation for services received

15 Peraturan Menteri Kesehatan Republik Indonesia, Kewajiban Pasien dalam Permenkes RI nomor 69 tahun 2014 tentang Kewajiban Rumah Sakit dan Kewajiban pasien (Republik Indonesia, 2014).

16 Undang-undang Republik Indonesia, Pasien dalam menerima pelayanan mempunyai kewajiban, terdapat pada Undang-Undang no. 29 Tahun 2004 tentang Praktik Kedokteran, 2004. 
According to Law of the Republic of Indonesia No. 38 Year 2014 in nursing practice, patients are obliged to: ${ }^{17}$

1. Provide true, clear, and honest information about their health problems.

2. Comply with the advice and instructions from nurses.

3. Obtain nursing services in accordance with the code of ethics, nursing service standards, professional standards, standard operating procedures, and provisions of laws and regulations.

4. Give approval or refusal of nursing actions to be received.

5. Obtain the confidentiality of his health condition. Disclosure of the client's health confidentiality is carried out on the basis of: The client's health interests, fulfillment of requests by law enforcement officials in the context of law enforcement, client's own approval, educational and research interests, and provisions of laws and regulations.

6. In addition, Article 32 of Law No. 44 Year 2009 concerning Hospitals regulates the rights received by patients at hospitals, including: patients have the right to receive services that are humane, fair, honest, and without discrimination; to obtain quality health services in accordance with professional standards and standard operating procedures. In addition, Article 43 regulates patient safety standards, which are carried out through incident reporting, analyzing, and determining solutions in order to reduce the number of unexpected events.

\section{B. Accountability for Negligence or Errors of Health Workers that Harm the Community}

Article 29 of Law No. 36 Year 2009 emphasizes the negligence or error of health workers as the cause of criminal problems. Everyone who feels aggrieved by negligence or error in the health services he receives has the right to claim compensation. This is regulated in Article 58 Paragraph (1) of Law No. 36 Year 2009

${ }_{17}$ Undang-undang Republik Indonesia, Dalam praktik keperawatan, kewajiban pasiean terdapat dalam Undang-Undang RI No. 38 Tahun 2014 tentang praktik keperawatan (Republik Indonesia, 2014). concerning Health which reads, "Everyone has the right to claim compensation to a person, health workers, and/or health providers who cause losses due to errors or negligence in the health services they receive". In the event that a health worker is suspected of having committed negligence or an error in health services that harms the patient as a member of the community, the negligence must be resolved first through mediation.

During the Covid-19 pandemic at this time and there are no signs that it will end, it is unavoidable that in health services there are health workers who neglect services, sometimes not in accordance with the rules. For example, the following case: ${ }^{18}$

"A number of people accompanied by a team of legal aid institution came to the District Court of Pematangsiantar City, North Sumatera, on Monday (29/6/2020). They came to sue the Head of the Task Force for the Acceleration of Handling Covid-19 who is also the Mayor of Pematangsiantar, Hefriansyah, for IDR 11 billion. The people who filed the lawsuit are former Covid-19 patients who were isolated and undergoing treatment at hospitals. However, they have now been declared cured. The lawsuit was filed by the 11 people because of an alleged error in determining the people positive for Covid-19, as well as the lack of medical treatment during isolation. This is considered very detrimental to the people. "This lawsuit is based on the authorities, the committee of the Task Force for the Acceleration of Handling Covid-19 is deemed by the people as victims with the aim of demanding compensation for material and immaterial damages," said the Legal Team of the LBH, Binaris Situmorang. One of the people who had undergone isolation, Abdul Wahid, said there was a team error in mentioning name so he had to be isolated. In fact, at that time the victim was sick with stomach acid. While other people think they have been accused of being exposed to Covid, there is absolutely

\footnotetext{
18 Muh Arafah, Keluarga Pasien Covid-19 Merasa Dirugikan, DPRD Akan Panggil Pihak RSUD Maspul Enrekang, 15 September th. 2020. https://upeks. co.id/2020/o9/keluarga-pasien-Covid-19-merasadirugikan-dprd-akan-panggil-pihak-rsud-maspulenrekang/
} 
no special treatment. The incident resulted in people experiencing losses because they could no longer carry out activities such as selling. Another consequence, people have to bear the risk of being ostracized by the community around Jalan Singosari Gang Demak, Pemangsiantar City. In addition to demanding that the lawsuit be granted, people who have been declared cured of Covid hope the Pematangsiantar City Government will restore their names who have been ostracized by others.

\section{Next case example: ${ }^{19}$}

Feeling aggrieved, Anipa (38), a former Covid-19 patient in Baubau City, Southeast Sulawesi (Sultra), sued the Palagimata Regional General Hospital (RSUD) and the Baubau Task Force, on Monday (26/10/2020). Anipa said that before being declared a Covid-19 patient, she was about to give birth and had a rapid test at the Wajo Public Health Center and was declared nonreactive. The lawsuit has been submitted to the District Court (PN) of Baubau and it is awaiting a schedule for hearing. Anipa sued because she did not accept being declared a COVID-19 patient in July 2020. With that status, Anipa felt aggrieved. However, after being referred to the Palagimata Hospital in Baubau City for delivery, Anipa underwent a rapid test again and the result was reactive. But the result of the rapid test was never shown by the hospital. This is what Anipa protested. According to her, the hospital is not transparent. Moreover, her health condition at that time was fine. "What annoyed me was that after giving birth the hospital did a swab test. After four days, I was declared positive for COVID-19. I refused to be isolated in the healthy home of the COVID-19 quarantine center," said Anipa. Meanwhile, Public Relations of the Baubau District Court, Hika D Asril Putra, said that there was a civil lawsuit filed by Anipa against the Palagimata Hospital and the Baubau COVID-19 Task

\footnotetext{
19 Andhy Eba, Merasa Dirugikan, Eks Pasien COVID-19 Gugat RSUDdan GugusTugas Baubau, 27 Oktober2020. https: //daerah.sindonews.com/read/20989o/174/ merasa-dirugikan-eks-pasien-Covid-19-gugat-rsuddan-gugus-tugas-baubau-1603746606. Diakses 6 Agustus 2021
}

Force, related to the determination process of COVID-19 patient.” Two parties were sued in connection with this case, namely the Palagimata Hospital and the Baubau COVID-19 Task Force.

Seeing these cases related to the criminal liability that hospitals have when health workers make negligence, criminal law recognizes two views, namely monism and dualism. The debate between the two views actually leads to the location of the fault in a criminal act. The monistic view views that when someone commits a criminal act, it means that they can automatically be held accountable. Strajbaarfeit is the same as the conditions for criminal prosecution. ${ }^{20}$

A different view from Dualism emphasizes that there is a separation between criminal act as an objective requirement and criminal liability as a subjective requirement. Herman Kontorowicz as a pioneer of the dualistic view argues that the fault is basically the nature of the behavior (merkmal der handlung). Therefore, for the existence of a criminal prosecution for the perpetrator (strafvoraussetzungen), it must be proven that there is strafbare handlung then one shall prove the subjective schuld of the perpetrator. ${ }^{21}$

From these two views, the views of two terms are very suitable to be applied in understanding fault as a subjective thing from the perpetrator of a criminal act. Regarding what is meant by fault, Sudarto distinguishes between Psychological Fault and Normative Fault in perpetrators. Psychological fault is an inner connection between the perpetrator and the desired or unwanted behavior regardless of the consequences. Regarding psychological fault, we know two forms of fault; willfulness and negligence. Meanwhile, normative fault has to do with criticism from outside (society) against the attitude of the perpetrator for violating the actions that should be done in society. ${ }^{22}$ "Fault is the mental state of the perpetrator and the inner relationship between the perpetrator and his action. ${ }^{23}$ As a

\footnotetext{
20 A.Z. Abidin, "Bunga Rampai Hukum Pidana” (Jakarta: Pradnya Paramita, 1983), 44.

21 Moeljatno, "Pidato Upacara Dies Natalis VI Universitas Gajah Mada, tanggal 19 Desember 1955," in Perbuatan Pidana dan Pertanggungjawaban dalam Hukum Pidana (Jakarta: Bina Aksara, 1955), 22-23.hlm 20

22 Sudarto, Hukum dan Perkembangan Masyarakat (Bandung: Sinar Baru, 1983).hlm 90-91

23 Muladi dan Dwidja Priyatno, Pertanggungjawaban Pidana Korporasi (Jakarta: Kencana, 2010). Hlm 73
} 
logical consequence of fault, one must be legally responsible as well as for health service errors that harm patients.

In accordance with the law that applies to the perpetrator of a criminal act, criminal liability must be asked for, except if the perpetrator commits an act because of an order or task so that criminal liability shifts to the giver of the order. That is why an understanding of fault cannot be separated from understanding of the subject of a crime, which means who commits the crime (the perpetrator) and who can be accounted for. All of this is very dependent on the formulation of liability made by the legislators. Hospital criminal liability is based on the Law through Article 46 of Law No. 44 Year 2009 although basically hospitals have legal responsibility for every action taken by health workers who work for them, specifically criminal responsibility. Schaffmeister emphasized the criminal liability relationship by saying "if the nature and purpose of the arrangement has shown indications for the criminal perpetrator, it is not important for the final proof of the criminal perpetrator, whether the act is in accordance with the statutory objectives of the legal entity and/ or in accordance with the company's policy, it is enough that the act is in accordance with the scope of work (feitelijke werkzaamheden). ${ }^{24}$

Therefore, when health workers make mistakes in providing health services that result in losses for patients, the hospital shall be legally responsible. Regarding the form or model of the hospital's criminal liability, it must be compared with the forms and models of liability that apply in criminal law. Mardjono Reksodiputro emphasized the 3 models of liability that had been implemented so far, namely:

1. It is the management of the corporation as the perpetrator and the management who shall be responsible;

2. The corporation as perpetrator and the management shall be responsible; and

3. The corporation as perpetrator and also as those who shall be responsible. ${ }^{25}$

If the three models of corporate criminal

${ }^{24}$ N. Keijzer dan E.PH. Sutorius. D. Schaffmeister, Hukum Pidana, ed. J.E. Sahetapy dan Agustinus Pohan (Bandung: Aditya Bakti, 2007). Hlm 282

25 Priyatno, Pertanggungjawaban Pidana Korporasi. Hal. 83 liability are compared with Article 46 of Law No. 44 Year 2009, it can be concluded that the 3rd model shall be applied. Indirectly, the legal provisions view that all actions taken by health workers in an employment relationship are actions by and on behalf of the hospital.

Meanwhile, in relation to the principle of responsibility, Article 46 of Law No. 44 Year 2009 does not apply either of these doctrines. The two doctrines basically do not require the existence of errors (mens rea) from the perpetrators of criminal acts $^{26}$, even though the formulation of Article 46 of Law No. 44 Year 2009 explicitly requires sickness. This kind of arrangement clearly raises questions for the legal protection that hospitals have when they have to be responsible for all negligence of their health workers. Therefore, an understanding of the legal rules in accordance with the principle of responsibility or liability is needed regarding the limits of hospital criminal liability.

With the patient safety standards regulated in Law No. 44 Year 2009 concerning Hospitals, events that cause death due to negligence or errors of medical personnel should be able to be avoided, considering that patient safety standards are clear and must be implemented. Law No. 36 Year 2009 concerning Health in Articles 4 to 8 regulates the rights of everyone to health. In Article 5 Paragraph (2), it is emphasized that everyone has the right to obtain safe, quality, and affordable health services. Everyone who feels aggrieved by negligence or error in the health services he receives has the right to claim compensation. This is regulated in Article 58 Paragraph (1) of Law No. 36 Year 2009 concerning Health which reads, "Everyone has the right to claim compensation to a person, health workers, and/or health providers who cause losses due to errors or negligence in the health services they receive.” In Law No. 29 Year 2004 concerning Medical Practice in Article 66 it is stated that any person whose interests are harmed by the actions of a doctor in carrying out medical practice can make a written complaint to the Chairman of the Indonesian Medical Discipline Honorary Council and in Paragraph (3) it is explained that even though a complaint has been made, it does not eliminate the rights of everyone to report suspected criminal acts to the competent authorities and/

${ }^{26}$ Romli Atmasasmita, Asas-asas Perbandingan Hukum Pidana (Jakarta: Yayasan Lembaga Bantuan Hukum Indonesia, 1983). Hlm 93 
or to sue for civil damages to the court. Law No. 44 Year 2009 concerning Hospitals in Article 46 reads "Hospitals shall be legally responsible for all losses caused by negligence committed by health workers in hospitals", so that hospitals are responsible for negligence of health workers who carry out work that is the responsibility of the hospital. The head's responsibility for medical personnel's errors regarding Emergency Patient Services related to Covid-19 in hospitals.

Emergency Situations. According to Article 1 point 4 of the Regulation of the Minister of Health number 47 Year 2018 concerning emergency, an emergency is a clinical situation that requires immediate medical action for rescue.

The role of doctors in emergency services is regulated in the following provisions:

1. Doctors in Emergency Services.

Article 11 of the Regulation of the Minister of Health Number 47 Year 2018 states that health resources who are working in emergency services are:

a. Doctor

b. Dentist

c. nurse; and/or

d. other health workers and non-health workers.

(3) Doctors, dentists, nurses, and/or other health workers as referred to in paragraph 2. It is stated that these resources must have emergency competence.

The person in charge of emergency health services is different in health facilities, as stated in Article 12 of the Regulation of the Minister of Health Number 47 Year 2018, namely:

a. In the event that Emergency Services are provided at Public Health Centers, Clinics, and Hospitals, the person in charge of the Emergency Services as referred to must be a doctor or specialist.

b. The doctor or dentist in charge of the service as referred to must be determined by the head of the Health Service Facility or the head or director of the Hospital.

c. Conditions are excluded for the independent practice of a Doctor or Dentist. Persons in charge of Emergency Services in independent practice site of other health workers shall be adjusted to the type of personnel who carry out the practice of health workers.
The criteria for emergency as referred to in paragraph (1) of the regulation of the Minister of Health Number 47 Year 2018 include:
a. threatening life, endangering self and others/ environment
b. there is a loss of consciousness
c. the presence of hemodynamic disorders; and/ or

d. requiring immediate action.

Emergency patients are people who are in threat of death and disability who require immediate medical action.

Patients who visit emergency service facilities come with different emergency levels, so that the Regulation of the Minister of Health Number 47 Year 2018 gives priority as follows:

a. priority 1 for a true emergency, must be helped immediately

b. priority 2 which is emergency but not urgent

c. priority 3 which is neither emergency nor urgent, or false emergency.

All priority 1 patients cannot wait and need immediate treatment (zero-minute response). Based on empirical experience, almost all critical patients experience functional or anatomical disorders of more than one organ system, where initial management must be carried out by a doctor and dentist who can carry out resuscitation procedures to an advanced level that can be carried out by a doctor and dentist who has emergency competence, able to work together as a team, proficient in communication, and able to see the patient holistically.

There are several priority categories of patients based on the emergency ${ }^{27}$

Category I: Must be helped immediately, people who need immediate treatment and must be treated by a medical team no later than two minutes after arriving at the ED, categorized as patients with critical life-threatening condition. For example, patients with cardiac arrest, respiratory arrest, and coma.

Category II: Emergency, patients in critical condition and in extreme pain, e.g., patients with severe chest pain, breathing difficulty or

\footnotetext{
${ }^{27}$ dr. Kevin Adrian, "Ini Dia Kondisi yang Harus Ditangani di UGD," https://www.alodokter.com/. Diakses 8 Juli 2021
} 
severe fractures, and convulsions. This condition is categorized as an emergency or has a lifethreatening condition, namely patients who require immediate treatment at least within 10 minutes of arriving at the ED.

Category III: Potentially worsening, People who need treatment at least within 30 minutes of arriving at the ED, categorized as important or urgent, namely patients who have potentially lifethreatening condition, for example suffering from severe illness, heavy bleeding from wounds,

Category IV: Serious but non-emergency condition, patients with moderate injury condition or symptoms, e.g., patients with foreign bodies entering the eyes, ankle sprains, migraines or earaches. These conditions fall into the category of serious but not emergency. Patients in this category require treatment for at least one hour after arriving at the ED.

Category V: Not urgent, patients with mild injury condition or symptoms, which usually have been experienced for more than a week, such as a rash or mild aches and pains, fall into the fifth category or condition that is not urgent. Patients in this category can wait up to a maximum of two hours, before being treated by a doctor.

The Integrated Emergency Management System which has been introduced by the Ministry of Health since 2004 has not been able to improve Emergency Services in Indonesia. Health Service Facilities in Indonesia in providing services are still traditional, which only functions as a reception room, where patients who come will be received by doctors or nurses. After performing interview and physical examination, the patient will be referred to the definitive section. Furthermore, patient management is carried out after the definitive doctor arrives or through instructions without seeing the patient's condition directly. This is far from the standard of modern Emergency Services, which prioritizes behavior or service culture that focuses on patients and their safety.

The Integrated Emergency Management System or IEMS is an integrated and call centerbased Emergency Victim/Patient service mechanism using the telecommunication access code 119 by involving the community.

This system is regulated by the regulation of the Minister of Health Number 19 Year 2016 concerning the Integrated Emergency
Management System, abbreviated as IEMS. The implementation of the IEMS consists of:
a. emergency communication system
b. Emergency Victim/Patient handling system;
c. emergency transportation system.

Emergency communication system, Emergency Victim/Patient handling system. The flow of IEMS implementation through call center 119 and Public Service Care or PSC are:28

1) Call center operators at the National Command Center will receive calls from people throughout Indonesia.

2) The call center operators will filter the incoming calls.

3) The call center operators will identify the service needs of the callers.

4) Emergency calls will be forwarded/ dispatched to District/City Public Service Care or PSC.

5) Furthermore, the required handling of the emergency will be followed up by the district/ city PSC.

6) Calls that require other health information and health complaints will be forwarded/ dispatched to Halo Kemkes (021-500567).

7) Emergency handling at the district/ city PSC includes emergency handling using algorithms, bed information needs, information on nearest health facilities, and ambulance information.

8) PSC is networked with health service facilities closest to the scene to mobilize or refer patients for emergency treatment.

The Emergency Management System aims to improve access and quality of emergency services and speedup response time for EmergencyVictims/ Patients and reduce mortality and disability rates.

Based on this research, if it is associated with the Grand Theory, it is the Theory of LM. Friedman, namely the legal system that is the framework of thought in this research, what is the understanding of the researcher of the legal system theory as proposed by L.M. Friedman associated with this research is that the legal substance, as

${ }^{28}$ Kementerian Kesehatan Republik Indonesia, Lampiran Peraturan Menteri Kesehatan Nomor 19 tahun 2016 tentang Sistem Penanggulangan Gawat darurat Terpadu (SPGT), n.d. 
an aspect of the legal system, is a reflection of the applicable rules, norms and behavior of the people in the system. Included in this concept is how people appreciate the formal rules that apply. This is where the concept of living law in the society emerges. Therefore, the concept of legal substance also includes what is produced by society. ${ }^{29}$

What about the legal culture? Legal culture is an attitude or appreciation of the community towards the law and the legal system. This component contains beliefs in the law, values, ideas and hopes. In other words, it is part of a general culture that is oriented towards the legal system. Ideas and opinions must be understood as things related to the development of the legal process. When it is said that Americans care deeply about litigation, they are actually talking about legal culture. ${ }^{30}$

For the people of Indonesia, the culture of helping people who need help should be a top priority because Indonesian culture is mutual cooperation, always helping those in need.

The legal structure, which will be given back, does not only describe the institutional aspect, but also includes the apparatus aspect. If what is being discussed is the Supreme Court, for example, then the discussion includes the judges. ${ }^{31}$ Therefore, the actions of the apparatus can be questioned. It seems that, in an empirical and dynamic situation, what the apparatus does cannot be separated from external influences, social forces, even though what the structure or apparatus must do cannot or must depart from the legal rules (substance). In this context, the legal substance is the basis of the work of the apparatus, because it is the rules that provide the basis for legitimacy to the authority of the apparatus. ${ }^{32}$

This authority should be the main priority of hospitals for patients who are in an emergency situation requiring hospital aid, even if doctors, nurses or the heads are unable to obtain this, the person concerned can be subject to punishment as stated in Article 190 paragraph (2) of the Health Law No. 36 Year 2009 concerning health.

\footnotetext{
29 Lawrence M. Friedman, American Law, New YorkLondon (New York: W.W. Norton \& Company, 1984).

3o Ibid. hal. 6

$31 \quad$ Ibid. hal. 218

32 Lawrence M. Friedman, The Legal Sistem, A Sosial Science Perspective. Russel (New York: Sage Foundation, 1975). Hlm 13
}

According to Lawrence Meir Friedman, these three elements are closely related to each other, like a machine where legal culture is the fuel that determines the life and death of the machine. The consequence of this aspect is that the legal culture is so urgent. Therefore, without legal culture, the legal system is helpless, like a dead fish lying in a basket, not like a living fish swimming in the ocean.

Lawrence Meir Friedman's theory of legal system in the context of legal structure, legal substance and legal culture is closely related to aspect of criminal act of violation by hospitals, especially in the context of rejection of emergency patients which is oriented to the dimensions of moral justice, legal justice, and social justice. This nature will give birth to, develop, and eventually lead to the culmination of legal objectives.

From the perspective of Gustav Radbruch's legal objectives where philosophical requirements will essentially create justice (gerechtigkeit), juridical requirements create legal certainty (rechts zekerheids) and sociological requirements create benefits (zweckmassigkeit). The theory of the true objective of law actually for the first time came from the polarization of thought by Herman Kontorowicz and was popularized by Gustav Radbruch. According to Gustav Radbruch, it is stated that the ideal of law is none other than justice. Furthermore, it is stated, "est autem jus a justitia, sicut a matre sua ergo prius fuit Justitia quormjus", meaning that law comes from justice as it was born from the mother's womb. Therefore, justice has existed before the law.

In addition, justice means a principle that must be applied in law enforcement. However, in the application of this principle, if inappropriately it can lead to criticism from the public in the field of state administration, its application can be loosened through or by using the "doelmaticheid" principle (benefit principle). For the sake of a greater benefit or because of a compulsion ( $a$ necessary of compelling end), the principle of deciding according to law (rechtmatigheid) can be loosened, even not applied. Not so in a judicial process. Judges are obliged to judge according to law. A trial conducted illegally is null and void (van rechtswegenieting). ${ }^{33}$

\footnotetext{
33 John Rawls, A Theory of Justice (Cambridge
} Massachusetts: Harvard University Press, 1976).hlm 1 
Legal substance, as an aspect of legal system, is a reflection of the applicable rules, norms and behavior of the people in the system. This concept includes how people appreciate the formal rules that apply. This is where the concept of living law in the society emerges. Therefore, the concept of Legal Substance also includes what is produced by the community.

What about legal culture? Legal culture means an attitude or appreciation of the community towards the law and the legal system. These components contain beliefs in the law, values, ideas and hopes. In other words, it is part of a general culture that is oriented towards the legal system. Ideas and opinions must be understood as things related to the development of the legal process. When it is said that Americans care deeply about litigation, they are actually talking about legal culture.

The legal structure, which will be given back, does not only describe the institutional aspect, but also includes the apparatus aspect. If what is being discussed is the Supreme Court, for example, the discussion includes the judges. Therefore, the actions of the apparatus can be questioned. It seems that, in an empirical and dynamic situation, what the apparatus does cannot be separated from external influences, social forces, even though what the structure or apparatus must do cannot or must depart from the legal rules (substance). In this context, the legal substance is the basis of the work of the apparatus, because the rules provide the basis for legitimacy to the authority of the apparatus.

Empirically, some rules are not used or used incorrectly by the apparatus. Legal structure and substance are real components in the legal system, but only as the best blueprint, not as a working machine. Therefore, the legal structure and substance cannot be described solely formally.

The term legal system as a part of the social system implies that the legal system cannot be isolated from the influences of social forces. How and what are the effects of the social system on law and through what social units this influence takes place. The social forces that are constantly at work in law can take the form which is "damaging", "continuing", "refreshing". Choosing which part of the law to use or not to use, whether to replace it, detour or take a shortcut (bypass); performing it openly or secretly, is the determinative effect of the operation of non-legal powers. All of them are aptly described as Legal Culture. Legal culture is a part of the general culture. The elements included in it are custom, opinion, way of working and thinking. This can be described as people's attitude towards the law (Attitude of Law).

The legal system, as a part of the social system, must be able to meet social expectations. Therefore, the legal system must produce something with a legal character (output of law) which is significantly related to social expectations. There are at least four things that must be produced or fulfilled by a legal system.

First, the legal system in general must be able to realize what the community hopes for the system.

Second, it must be able to provide a normative schema. However, the function of conflict resolution is not merely a monopoly of the legal system. But at least as a basic function, the legal system must be able to provide a mechanism and a place where people can bring their cases to be resolved.

Third, the legal system as social control. The essence is that the police and judges, for example, must enforce the law. With regard to social control, the legal system must provide normative guidance for law enforcement apparatus in law enforcement.

Fourth, in relation to the function of social control, the urge of social forces to make law must be responded to by legal institutions, crystallized, included into the legal rules, and determined for the principles. In this context, the legal system can be said to be an instrument of change in social order, or social engineering. The legislature, for example, can play this role.

In contrast to economic power, legal force and power are not easily described because they are abstract. Although power, as well as its influence, is a real phenomenon. The impact is seen in the model and form of law. The influence of these three factors, when compared, can be said to be large or small, as well as more or less. Therefore, power, influence and social force cannot be imagined as separate units. When making a law, a legislator will think about whether the law to be made harms other groups, and he realizes, no one is openly against it. It is true that the supremacy of law, as well as the formation of law, is seen as a creation of power. 
The weight of the important relationship between Friedman's theory and this research according to the researcher lies in the following factors:

1. The emergence of development and formulation of policies on the form, regulations and handling in health services and hospitals takes place in a social order that is filled with values and orientation expectations that develop in society. These forces determine and influence each other.

2. Policy reform in the health sector, especially in the service of emergency patients, is the culmination of a mere debate. If it is seen from the current situation, as in several cases mentioned by the researcher in the initial discussion of this research.

3. The trial conducted by the legislature in the overall discussion of the community contained 2 (two) events at once, namely law and politics. Both elements are included in the concept of "Legal Culture". This choice is also supported by the thought of Frans Magnus Suseno, ${ }^{34}$ in order to find the feelings of the community, all elements relevant to legal order must be taken into account. These elements are values, norms of life, patterns and structures of life, as well as social relations. In this context, it will be seen what is fair and what is not.

From the description of the Legal System above, the Legal System in Indonesia consists of:

1. Structure or apparatus, namely executive, legislative and judiciary

2. Substance, namely:

a. Laws and regulations from the Constitution to the Ministerial Circular

b. Court Decision

3. Legal Culture, namely how the public, including the executive, legislative, and judiciary, perceives the law.

The relationship of this theory to the overall law in providing services to emergency patients in the setting of patient first aid, which should be a priority of attention are:

For the government,

\footnotetext{
34 Frans Magnus Suseno, Etika Politik, Prinsip-Prinsip Moral Dasar Kenegaraan Modern (Jakarta: Gramedia, 1994). Hlm 112
}

1. here the structure or apparatus is the Ministry of Health of the Republic of Indonesia which is responsible for the health sector

2. Substance; which will regulate the basis of the discussion is Law Number 36 Year 2009, Law Number 44 Year 2009 and several ministerial regulations, including: Ministerial Regulation Number 19 Year 2016 concerning Integrated Emergency Management System.

3. Meanwhile, regarding legal culture, there are 2 (two) conflicting perceptions regarding the process of handling emergency patients, one of which is by refusing that hospital facilities are insufficient or the absence of doctors which causes the emergency patient to be rejected. This is not in accordance with the legal culture of the Indonesian people who always provide help to others.

\section{CONCLUSION}

Regarding health services in hospitals that are detrimental to patients, especially during the Covid-19 pandemic, criminal liability and prosecution of hospitals as legal entities raise several juridical implications and problems. Positive legal provisions stipulate that hospitals and/or doctors shall not refuse to provide services to patients, both who are sick and who are in emergency. Hospitals as legal entities should be responsible for all forms of actions carried out by both doctors and nurses.

Regarding fault and proof of criminal acts, the psychological state of the perpetrator does not have to be proven or considered first, because fault in criminal acts is fault that is oriented towards actions that are objective normative in nature. An assessment of the psychological state of the perpetrator is carried out when researching the ability to be responsible. The ability to be responsible, which is the psychological state of the perpetrator, is a psychological element of criminal liability so that it is different from fault as an element of a normative crime. People who can be held criminally accountable are perpetratororiented. Not so in the justice process because the judge is obliged to judge according to law. A trial that is not carried out according to the law is null and void. Then, to get a sense of justice, it must be carried out in accordance with the legal system such as legal substance, legal structure and legal culture. 


\section{SUGGESTION}

The suggestions/recommendations that can be submitted by the researcher as proposals for the government and the House of Representatives in providing protection to emergency patients in various ways are as follows:

Carry out an ideal reconstruction of Law Number 36 Year 2009 especially regarding Article 190 Paragraph (1) and Paragraph (2). Article 190 Paragraph (1): Heads of health service facilities and/or health workers who practice or work at health service facilities who intentionally do not provide first aid to patients in an emergency situation as referred to in Article 32 Paragraph (2) or Article 85 Paragraph (2) shall be sentenced to imprisonment for a maximum of 2 (two) years and a maximum fine of IDR 200,000,000,- (two hundred million rupiah). Article 190 Paragraph (2): In the event that the act as referred to in paragraph (1) results in disability or death, the head of the health service facility and/or health worker shall be sentenced to imprisonment for a maximum of 10 (ten) years and a maximum fine of IDR 1,000,000,000,- (one billion rupiah).

Article 1 number 2 of Law Number 36 Year 2014 concerning Health Workers states that: "Health facilities are places which are used to carry out health efforts." In the Decree of the Minister of Health of the Republic of Indonesia No. 129 Year 2008 concerning Minimum Service Standards for Hospitals, it is stated that every hospital is required to have a minimum service standard.

Minimum service standards are provisions regarding the type and quality of basic services which are mandatory regional affairs that every citizen has the right to obtain at a minimum, including people infected with the Covid-19. In addition, it is also a technical specification regarding the minimum service standards provided by the Public Service Agency. This minimum service standard can be used as a reference for hospital managers and related elements in planning, financing and implementing each type of service.

\section{ACKNOWLEDGMENT}

The researcher would like thank those who have helped in writing this article. Hopefully this paper is useful and becomes a source of knowledge, especially in the field of law.

\section{BIBLIOGRAPHY}

Abidin, A.Z. "Bunga Rampai Hukum Pidana.” 44. Jakarta: Pradnya Paramita, 1983.

Adrian, dr. Kevin. "Ini Dia Kondisi yang Harus Ditangani di UGD.” https://www.alodokter. $\mathrm{com} /$.

Alika, Rizky. "Terlambat Masuk Rumah Sakit, 20\% Pasien Covid-19 Meninggal di IGD.” https://katadata.co.id/. Last modified 2021. https://katadata.co.id/ameidyonasution/ berita/6107a351b76e3/terlambat-masuk- r umah-saki t-20 -pas i en - Covid-19 meninggal-di-igd.

Atmasasmita, Romli. Asas-asas Perbandingan Hukum Pidana. Jakarta: Yayasan Lembaga Bantuan Hukum Indonesia, 1983.

Budiono, Eko. "Ganti Rugi atas Kelalaian dan Kesalahan dalam Pelayanan Kesehatan”." https://ekobudiono.lawyer/. Last modified 2020.https://ekobudiono.lawyer/2020/09/26/ ganti-rugi-atas-kelalaian-dan-kesalahandalam-pelayanan-kesehatan/.

D. Schaffmeister, N. Keijzer dan E.PH. Sutorius. Hukum Pidana. Diedit oleh J.E. Sahetapy dan Agustinus Pohan. Bandung: Aditya Bakti, 2007.

Darmadi. Infeksi Nosokomial Problematika Dan Pengendaliannya, Salemba Medika. Jakarta: Salemba Medika, 2008.

Friedman, Lawrence M. American Law, New York-London. New York: W.W. Norton \& Company, 1984.

- The Legal Sistem, A Sosial Science Perspective. Russel. New York: Sage Foundation, 1975.

Indonesia, Kamus Besar Bahasa. "Pengertian Pasien.” Jakarta: https://kbbi.web.id, 2021. https://kbbi.web.id/pasien.

Indonesia, Kementerian Kesehatan Republik. Lampiran Peraturan Menteri Kesehatan Nomor 19 tahun 2016 tentang Sistem Penanggulangan Gawat darurat Terpadu ( SPGT ), n.d.

Indonesia, Peraturan Menteri Kesehatan Republik. Kewajiban Pasien dalam Permenkes RI nomor 69 tahun 2014 tentang Kewajiban 
Rumah Sakit dan Kewajiban pasien. Republik Indonesia, 2014.

Indonesia, Undang-Undang Republik. Lihat Pasal 32 Undang-undang nomor 36 tahun 2009 tentang kesehatan ayat (1) dan (2). Republik Indonesia, 2009.

Indonesia. Undang-Undang Nomor 44 Tahun 2009 tentang Rumah Sakit. Republik Indonesia, 2009.

Moeljatno. "Pidato Upacara Dies Natalis VI Universitas Gajah Mada, tanggal 19 Desember 1955.” In Perbuatan Pidana dan Pertanggungjawaban dalam Hukum Pidana, 22-23. Jakarta: Bina Aksara, 1955.

Nasution, A.Z. Hukum Perlindungan Konsumen Suatu Pengantar, Jakarta: Diadit Media, 2001, hlm. 3. Jakarta: Diadit Media, 2001.

Priyatno,MuladidanDwidja.Pertanggungjawaban Pidana Korporasi. Jakarta: Kencana, 2010.

Rawls, John. A Theory of Justice. Cambridge Massachusetts: Harvard University Press, 1976.

Soekanto, Soerjono. Segi-Segi Hukum Hak Dan Kewajiban Pasien dalam Krangka Hukum Kesehatan. Jakarta: CV Mandar Maju, 1990.

Sudarto. Hukum dan Perkembangan Masyarakat. Bandung: Sinar Baru, 1983.

Suparto Wijoyo. "Webinar Nasional." In Tantangan New normal dan dampaknya terhadap Rekonstruksi Hukum Lingkungan. Surabaya: PPI UINSA 28 Agustus 2020, 2020.

Suseno, Frans Magnus. Etika Politik, PrinsipPrinsip Moral Dasar Kenegaraan Modern. Jakarta: Gramedia, 1994.

Titik Triwulan Tutik dan Shita Febriana. Perlindungan Hukum Bagi Pasien. Jakarta: Prestasi Pusataka, 2010.

Undang-undang Republik Indonesia. Dalam praktik keperawatan, kewajiban pasiean terdapat dalam Undang-Undang RI No. 38 Tahun 2014 tentang praktik keperawatan. Republik Indonesia, 2014.

Undang-undang Republik Indonesia. Pasien dalam menerima pelayanan mempunyai kewajiban, terdapat pada Undang-Undang no. 29 Tahun 2004 tentang Praktik Kedokteran, 2004.
Wiradharma, Danny. Penuntun Kuliah Hukum Kedokteran. Jakarta: CV Sagung Seto, 2010.

Yustina, Endang Wahyati. Mengenal Hukum Rumah Sakit. Bandung: Keni Media, 2012. 